\title{
Analisis Rasio Pendapatan Petani Sayuran Sawi Dengan Petani Padi Di Kecamatan Sukorambi Kabupaten Jember
}

\author{
Suherman \\ STIE Mandala, Jember
}

\begin{abstract}
Agirbisnis in the field of food crops, especially Mustard vegetables and rice have favorable prospects. The mustard vegetable farming in the Sokorambi sub-district on a micro scale, is a hereditary effort with traditional methods, the title of this research is: Analysis of the ratio of mustard vegetable growers to rice farmers in Sukorambi District, Jember Regency. The specific objectives of this study are: To find out the reasons why farmers prefer to grow mustard or rice vegetables, to analyze the comparison of farmers' income between planting mustard vegetables and planting rice.The method used for achieving goals is: Profit Analysis, Analysis of farm efficiency with the $R / C$ Ratio approach, Comparison of income of mustard vegetable farmers with rice farmers. The results showed that the $R$ / $C$ ratio for the two commodities is greater than one, which shows that it is worth trying. The advantage of mustard vegetable farmers is significantly different compared to the benefits of rice farmers.
\end{abstract}

Keywords: Agribusiness, Micro-scale Business, $R$ / C Ratio, Revenue

\section{Pendahuluan}

Pemerintah orde baru dalam pembangnan jangka panjang tahap pertama, tepatnya repelita III telah berhasil mencapai swasembada pangan. Pada periode 1984-1993 produksi pertanian domestik melebihi kebutuhan pangan. Revitalisasi pertanian, perikanan, dan kehutanan (RPPK) mengamanatkan pembangunan ketahanan pangan yang mantap (termasuk gula) dengan memfokuskan pada peningktana kapasitas produksi nasional untuk lima komoditas pangan strategis , yaitu Padi, Jagung, Kedelai,Tebu dan Daging Sapi , Deptan (2005 ). Komoditas strategis lainnya yang tidak kalah pentingnya adalah hortikultura seperti sayursayuran, buah-buahan dan tanaman hias.

Pada tahun 2016 tanaman padi untuk Kabupaten Jember memiliki luas panen 166178,90 Ha dengan produksi mencapai $986653 \mathrm{Kw}$,sedangkan untuk 
Kecamatan Sukorambi pada tahun 2016 luas panen padi sebesar 4161.70 dengan total produksi mencapai $24812 \mathrm{Kw}$ (BPS Jember Tahun 2017).

Pertanian dalam arti luas meliputi tanaman pangan, perkebunan, perikanan dan kehutanan.Pertanian dalam arti sempit menyangkut tanaman pangan seperti hortikultura yang meliputi sayur-sayuran, buah - buahan dan tanaman hias. Kabupaten Jember dengan luas wilayah lebih kurang 3.293,34 km persegi, yang berada di belahan timur Jawa Timur di kenal sebagai daerah agraris dan penghasil berbagai komoditas pertanian, hortikultura dan perkebunan. Pada tahun 2016 luas panen di Kabupaten Jember untuk tanaman sayuran sawi mencapai $186 \mathrm{Ha}$, dengan total produksi 7939 kwt. Khusus di Kecamatan Sukorambi Kabupaten jember sayuran sawi pada tahun 2016 luas panennya mencapai $105 \mathrm{Ha}$ dengan total produksi mencapai $4141 \mathrm{Kw}$ (BPS Jember, 2017):

Bagi masyarakat Sukorambi Budidaya sayuran sawi merupakan usaha yang bersifat turun temurun, karena ditunjang oleh lingkungan yang memungkinkan seperti ketersediaan air yang cukup.

Sayuran -sayuran seperti : Bawang merah, Kubis, Kol, Sawi, Kacang Panjang, Cabe besar dan kecil, Tomat Terung, Buncis dan ketimun, bayam dan kangkung memiliki daya saing sendiri-sendiri. Dilihat dari fungsinya ,budidaya komoditi hortikultura ( buah-buahan, sayur-sayuran dan tanaman hias ) disamping diarahkan untuk memperbaiki gizi masyarakat juga meningkatkan pendapatan petani dan penyediaan lapangan kerja.

Sayur-sayuran secara garis besar dapat diklasifikasi menjadi tiga, yaitu sauran daun (bayam,kangkung,gubis,sawi), sayuran umbi (kentang,wortel,bawang merah, bawang putih), sayuran buah (tomat,kacang panjang, buncis, cabai).

Disamping pembagian tersebut diatas, sayur-sayuran juga dapat diklasifikasi berdasrkan geografisnya, yaitu :sayuran dataran rendah dan sayuran dataran tinggi. Sayruran dataran rendah berupa cabai sebagai komoditi utama, komoditi kedua adalah bawang merah dan kacang-kacangan.Sedangkan komoditi ketiga adalah bayam, kangkung,sawi dan ubi kayu.Sayuran dataran tinggi yang utama adalah kentang, kubis,bawang putih,wortel selada dan buncis.

Budidaya komoditi sayuran pada umumnya ditujukan untuk kepentingan 
pasar, sehingga masalah pemasaran merupakan masalah yang penting dan perlu mendapatkan perhatian khusus untuk meningkatkan kegairahan berproduksi bagi produsen. Ini menunjukkan bahwa ada hubungan yang erat antara kegiatan produksi ( usaha tani ) dengan kegiatan pemasaran.

Dalam hal distribusi komuditi sayur-sayuran sawi dari sentra produksi ke sentra konsumen, peranan lembaga pemasaran termasuk pengecer memegang peranan penting.Karena sifat pisik dari sayuran mudah rusak, maka faktor kecepatan pemasaran sangat di perlukan.

Keberhasilan didalam meningkatkan taraf hidup petani sayur tidak hanya dipandang dari berhasil atau tidaknya dari segi agronomis, tapi juga harus dipandang dari segi ekonomis yaitu dari aspek pemasarannya . Justru dari aspek pemasaran inilah yang menjadi titik lemah bagi produsen. Ditinjau dari segi bercocok tanam kecuali faktor musim, petani harus memahami betul tentang kualitas bibit,dosis pupuk, pemberantasan hama dan penyakit serta masalah kebutuhan air. Permintaan terhadap sayuran cukup besar, dalam arti bahwa berapapun produksi sawi yang di hasilkan oleh petani habis terjual kepada para pedagang.

Masalah dan tantangan petani sayur menyangkut dua aspek, yaitu aspek manajemen usaha tani dan aspek manajemen pemasaran. Aspek usaha tani adalah bagaimana bisa mengelola usaha tani sayur -sayuran yang efektif dengan penekanan pada efisiensi. Aspek manajemen pemasaran menyangkut kapan mulai budidaya tanaman sayuran, perencanaan bagaimana menjualnya, sistim apa yang akan di pakai, pemikiran faktor -faktor apa yang mempengaruhi harga di tingkat produsen, apakah petani sawi bisa menjual produk sehingga mempunyai nilai tambah yang bisa meningkatkan pendapatan.

Petani sayuran Sawi dan Padi dilahat dari manajemen usaha tani ataupun manajemen pemasaran harus bijak dalam mengambil keputusan, hal ini karena sayuran Sawi dan Padi memiliki daya saing yang berbeda-beda. Kesalahan dalam mengambil keputusan akan berdampak pada pendapatan yang akan diterima oleh petani sayuran Sawi dan Padi. 
Dari uraian di atas maka dapat di rumuskan beberapa permasalahan dalam penelitian ini 1. Bagaimana petani mengambil keputusan untuk menanam sayur sawi atau padi?. 2.Manakah yang paling menguntungkan antara menanam sayuran sawi di banding dengan menanam padi?

\section{Urgensi Penelitian}

Desa Sukorambi Kecamatan Sukorambi Jember di kenal sebagai daerah sentra produksi sayuran sawi. Manajemen usaha tani sawi maupun padi di Kecamatan Sukorambi Jember tergategori sudah baik, karena usaha tani sayuran sawi dan padi sudah bersifat turun temurun dan diperkuat dengan kelembagaan usaha tani seperti Kelompok-kelompok tani, Penyuluh pertanian lapangan (PPL ), sehingga petani dapat meningkatkan produktivitas sayuran sawi dan padi.

Keberhasilan di bidang budi daya kalau tidak di ikuti dengan keberhasilan di bidang pemasaran tidak akan meningkatkan pendapatan petani. Komoditi sayuran sawi dan padi tidak mengalami kesulitan dalam pemasarannya. Keterbatasan petani sayur dalam mengambil keputusan untuk menenam sayuran sawi dan padi akan berdampak pada pendapatan dari usaha tani. Oleh karena itu perlu di ketahui dan dianalisis rasio pendapatan tanaman sayuran sawi dengan tanaman padi

\section{Tinjauan Pustaka}

\section{Penelitian Terdahulu.}

Hasil penelitian Maspur dan Shophal Jamil (2007) yang berjudul Analisis Daya Saing Beberapa Jenis Sayuran Di Lahan Sawah menyimpulkan Usaha tani Cabai merah besar lebih memiliki daya saing tehadap Uasahatani bawang merah dan kubis berdasarkan kreteria keuntungan ,R/C Rasio.

Edy Sutiarso dalam tulisannya yang berjudul Analisis Daya Saing Agribisnis Bawang Merah Di Kabupaten Probolinggo menyimpulkan :

1. Agribisnis bawang merah di Kabupaten Probolinggo masih menguntungkan dan layak untuk tetap di usahakan, baik secara finansial (Rp.34,9 juta ha/musim ) maupun ekonomi (Rp.23,9 juta ha/musim). 
2. Agribisnis bawang merah di Kabupaten Probolinggo masih memiliki daya saing,baik keunggulan komparatif ( $\mathrm{PCC}=0,222$ ) dengan daerah lain, maupun keunggulan komparatif ( $\mathrm{DRCR}=0,291$ ) dengan negara lain

3. Keunggulan komparatif sangat sensitif terhadap perubahan input,produktivitas dan harga output,tetapi tidak terpengaruh oleh perubahan nilai tukar.Sementara keunggulan komparatif selain sensitif terhadap perubahan produktifitas, harga input dan harga output, juga peka terhadap perubahan nilai tukar.

4. Kebijakan pemerintah terhadapharga input tradeable (subsidi harga input) berdampak positif terhadap kemampuan daya saing komoditas bawang merah yang dihasilkan petanidi Kabupaten Probolinggo.Sementara dampak terhadap harga input tidak ada. Harga output terbentuk karena mekanisme pasar,bukan diakibatkan oleh adanya intervensi pemerintah.

Muhammad Firdaus ( 2016), Dalam penelitiannya yang berjudul : Skala Prioritas Dan Strategi Pengembangan Usahatani Hortikultura Di Kabupaten Jember menyebutkan keuntungan hortikultura di Kabupaten Jember khusus untuk sayuran Terung,Kubis,Kacang panjang,Buncis,Timun,Tomat,Cabe Rawit,Cabe besar memiliki R/C Ratio sabagi berikut : 1.97, 1.72, 1.43, 2.42, 1.77, 2.18, 2.54, 3.82.

Ramli dan Dewa KS Swastika (2005) ,dalam penelitiannya yang berjudul Analisis Keunggulan Komparatif Beberapa Tanaman Palawija di lahan pasang Surut Kalimantan Tengah,menyebutkan :

1. Titik Impas Harga sebesar Rp.1.180.Jadi jika pada saat penjualan hasil produksi , petani melepas dengan harga Rp.1.180, maka Petani tersebut tidak mengalami kerugian.

2. Titik impas Produksi sebesar 3,6 Kwt.Jadi jika pada saat panen ,Petani hanya memperoleh hasil sebesar 3,6 Kwt, maka berarti Petani tidak mengalami kerugian.

\section{Pengertian Pertanian dan Peran Pemerintah}

Pengertian pertanian menurut Muhammad Firdaus ( 2007) ada dua yaitu dalam arti sempit dan dalam arti luas. Dalam arti luas mencakup : pertanian rakyat,Perkebunanan,Kehutanan, Peternakan dan Perikanan. 
Pertanian dalam arti sempit menyangkut tanaman pangan seperti padi dan hortikultura ( Buah-buahan, Tanaman hias dan Sayur-sayuran )

Pengertian agribisnis dalam arti sempit menyangkut perdagangan atau pemasaran hasil -hasil pertanian. Dalam arti luas menyangkut kegiatan usaha yang menghasilkan/menyediakan prasarana/sarana/input bagi kegiatan pertanian (Industri pupuk,alat-alat pertanian,pestisida dan lain sebagainya ), Kegiatan pertanian ( Usaha Tani,Pengolahan ), dan Kegiatan usaha yang menggunakan hasil pertanian sebagai input( Industri pengolahan hasil pertanian,perdagangan dan sebaginya.

Dilihat dari kepemilikan/metodenya ,ada pertanian yang subsisten (Tradisional) dimana tujuan pegelolaannya hanya untuk kepentingan sendiri dengan metode bertani yang sangat sederhana;ada yang modern, dimana produksinya tidak hanya untuk memenuhi kebutuhan sendiri tapi untuk kepentingan masyarakat luas baik dalam skala nasional maupun internasional.Pertanian dalam skala ini sudah bersfat komersial dan sudah bersentuan dengan tehnologi. Dalam skala ini pertanian sadah memperhatikan keunggulan kompetitif dan keunggulan komparatif. Sebagian besar penduduknya bersandar pada sektor pertanian.Pembangunan di sektor pertanian memegang peranan penting dalam rangka untuk mensejahterakan masyarakatnya.Bidang petanian terlalu amat luas,peluang usaha terbuka lebar. Pada masa Pemerintahan Orde Baru sektor Pertanian pernah menjadi fokus utama minimal targetnya adalah swasembada pangan dan meningkatkan eksport.

Untuk mengatasi kegagalan pasar (market failure) seperti kekakuan harga, monopoli, dan eksternalitas yang merugikan maka peran pemerintah sangat diperlukan dalam perekonomian suatu negara. Peranan ini dapat dilakukan dalam bentuk intervensi secara laungsung maupun tidak langsung. Berikut adalah intervensi pemerintah Indonesia secara langsung dan tidak langsung dalam penentuan harga pasar untuk melindungi konsumen atau produsen melalui kebijakan penetapan harga minimum (floor price) dan kebijakan penetapan harga maksimum ( Ceiling Price ).

Penetapan harga minimum atau harga dasar yang dilakukan oleh pemerintah 
bertujuan untuk melindungi produsen, terutama untuk produk dasar pertanian. Misalnya harga gabah kering terhadap harga pasar yang terlalu rendah. Hal ini dilakukan supaya tidak ada tengkulak (orang/pihak yang membeli dengan harga murah dan dijual kembali dengan harga yang mahal) yang membeli produk tersebut diluar harga yang telah ditetapkan pemerintah. Jika pada harga tersebut tidak ada yang membeli, pemerintah akan membelinya melalui BULOG (Badan Usaha Logistik) kemudian didistribusikan ke pasar. Namun, mekanisme penetapan harga seperti ini sering mendorong munculnya praktik pasar gelap, yaitu pasar yang pembentukan harganya di luar harga minimum.

Penetapan harga maksimum atau Harga Eceran Tertinggi (HET) yang dilakukan pemerintah bertujuan untuk melindungi konsumen. Kebijakan HET dilakukan oleh pemerintah jika harga pasar dianggap terlalu tinggi diluar batas daya beli masyarakat (konsumen). Penjual tidak diperbolehkan menetapkan harga diatas harga maksimum tersebut. Contoh penetapan harga maksimum di Indonesia antara lain harga obat-obatan diapotek, harga BBM, dan tariff angkutan atau transportasi seperti tiket bus kota, tarif kereta api dan tarif taksi per kilometer. Seperti halnya penetapan harga minimum, penetapan harga maksimum juga mendorong terjadinya pasar gelap.

Penetapan harga minimum dan harga maksimum atau Harga Eceran Tertinggi (HET) yang dilakukan oleh pemerintah,hanya terbatas pada barang kebutuhan pokok seperti beras. Petani padi/beras tidak bisa menetukan harga pokok produksi di tambah dengan keuntungan yang di harapkan menjadi harga jual. Hal ini terjadi karena ada campur tangan pemerintah dalam menentukan harga jual produksinya seperti padi ( gabah).

Tanaman pangan sayuran seperti Sawi, penentuan harganya tidak mengikuti regulasi yang ditetapkan oleh Pemerintah, sepenuhnya terserah pada kekuatan pasar.

Produk pertanian tidak bisa disamakan dengan produk industri.Produk industri dapat dengan mudah memenuhi kebutuhan pasar, hal ini berarti jika produk industri harganya meningkat di pasar, maka produsen industri dapat dengan mudah menambah supply ke pasar. Lain halnya dengan produk -produk pertanian. Produk 
pertanian memiliki ciri-ciri khusus..Beberapa ciri produk pertanian Menurut Soekartawi antara lain:

a) Produk pertanian adalah musiman, artinya tidak dapat diproduksi setiap saat

b) Produk pertanian bersifat segar dan mudah rusak

c) Produk pertanian bersifat bulky, artinya volumenya besar tapi nilainya relative kecil

d) Produk pertanian tertentu dapat berfungsi sebagai produk social, bila harga beras berubah sedikit saja maka masyarakat akan cepat menjadi gelisah.

\section{Manajemen Agribisnis}

Manajemen Agribisnis pada prinsipnya merupakan aplikasi dari penerapan manajemen dalam bidang pertanian dalam arti luas. Oleh karena itu seseorang yang terjun dalam agribisnis harus memahami benar tentang konsep-konsep manajemen seperti Pengertian manajemen, fungsi manajemen,tingkatan manajemen, prinsipprinsip manajemen.Manajemen yang terintegrasi sangat di perlukan dalan agribisnis,karena agribisnis bidangnya sangat luas dan terbagi dalam subsistemsubsistem.Namun demikian aplikasinya berbeda tergantung pada karakteristik usaha,jenis produk yang dihasilkan,dan skala usaha.

Aplikasi Fungsi -Fungsi Manajemen :

a. Fungsi Perencanaan.

Banyak faktor yang harus diperhatikan dama membuat perencanaan dalam agribisnis,antara lain : karakter alamiah komoditas,faktor musim,kondisi lahan,kemungkinan seangan hama dan penyakit, inilah yang membedakan dengan bisnis lainnya.

Adapun langkah-langkah kegiatan dalam membuat perencanaan agribisnis meliputi antara lain : melakukan identifikasi kebutuhan pasar,kebutuhan industri hilir,jaringan pensuply input, ketersediann modal usaha, penyusunan usaha tani yang memiliki keunggulan kompetitif dan sebagainya.

b. Fungsi Pengorganisasian

Pengorganisasiana menyangkut bagaimana mendesain perencanaan dalam sebuah struktur organisasi yang tepat, tanggug,kondusif dan dapat dipastikan 
bahwa semua unsur dan pihak yang terlibat dalam organisasi dapat bekerja secara efektif dan efisien untuk mencapai tujuan usaha di bidang agribisnis.

c. Fungsi aktifitas.

Setelah perencanaan agribisnis debuat secara detail, kemudian di organisir,maka langkah selanjutnya adalah mengoperasikan usaha di bidang agribisnis. Dalam mengoperasikan agribisnis harus mengedepankan konsep efektifitas, efisiaensi dan mutu produk akhir.

Dalam proses produksi mungkin juga terjadi barang yang dihasilkan tidak sesuai dengan apa yang telah direncanakan, tapi untuk produk akhir tidak boleh terjadi untuk mencapai tujuan bisnis.

\section{d. Fungsi Pengawasan}

Fungsi pengawasan tidak dimaksudkan semata-mata mencari kesalahan, melainkan sebagai evaluasi antara apa yang telah dikerjakan betul-betul sesuai apa tidak dengan apa yang telah di rencanakan.Oleh karena itu sangat perlu dibuat sistem pengawasan ang baku dimana di setiap penyimpangan dapat dengan cepat terdeteksi dan menjamin bahwa suatu siatem dapat berjalan sebagaimana mestinya.

\section{Teori Permintaan dan Penawaran}

Permintaan adalah sejumlah barang dan jasa yang dibutukan oleh konsumen pada saat dan harga tertentu, sedangkan penawaran adalah sejumlah barang dan jasa yang sanggup ditawarkan oleh perodusen pada saat dan harga tertentu.Sehingga permintaan datangnya dari konsumen dan penawaran berasal dari produsen.

Cara menyatakan permintaan dan penawaran bisa dilakukan dengan tabulasi, grafik ( Kurve) dan matematis. Hal ini tentunya di sesuaikan ndengan kebutuhan.

Keseimbangna Pasar secara grafis adalah perpotongan antara kurve permintaan dan kurve penawaran, dimana pada saat terjadi perpotangan jumlah barang yang di minta sama dengan jumlah barang yang ditawarkan pada saat harga keseimbangan..

Menurut Muhammad Firdaus ( 2012), Keadaan suatu pasar dikatakan dalam keseimbangan atau ekuilibrium apabila jumlah yang ditawarkan para penjual pada 
suatu harga tertentu adalah sama dengan jumlah yang diminta oleh pembeli pada harga tersebut. Harga keseimbangan adalah harga dimana,baik konsumen maupun produsen sama-sama tidak ingin menambah atau mengurangi jumlah yang dikonsumsi dan yang di jual. Jika harga diabwah harga keseimabganagn,terjadi kelebihan pemintaan,sebab permintaan akan meningkat dan penawaran menjadi berkurang.Sebaliknya,jika harga melebihi harga keseimbangnan,terjadi kelebihan penawaran. Jumlah penawaran meningkat,Jumlah permintaan menurun. Ada dua cara yang dapat digunakan untuk menunjukkan keadaan keseimbangan ,yaitu :

a) Menggunakan angka

b) Menggunakan kurve permintaan dan penawaran.

\section{Konsep Agribisnis Pertanian}

Agribisnis merupakan sistem pertanian yang saling terkait mulai dari sistem hulu sampai dengan sistem hilir yang memanfaatkan sumber daya yang ada dengan tujuan mendapatkan keuntungan yang sebesar-besarnya. (Saragih,1997)

Industri hulu adalah sektor yang memproduksi alat-alat dan mesin pertanian serta industri sarana produksi yang digunakan dalam proses budidaya pertanian.

Sementara industri hilir merupakan industri yang mengolah hasil pertanian menjadi bahan baku atau barang yang siap dikonsumsi atau merupakan industry pascapanen dan pengolahan hasil pertanian.

Adapun rantai atau subsistem tersebut dapat diuraikan sebagai berikut:

a. Subsistem Penyediaan Sarana Produksi seperti: mesin -mesin untuk pengolahan tanah,benih, bibit, makanan ternak, pupuk, obat pemberantas hama dan penyakit, lembaga perbankkan, bahan bakar, peralatan produksi pertanian. Pelaku-pelaku kegiatan pengadaan dan penyaluran sarana produksi bisa perorangan, perusahaan swasta, pemerintah, koperasi.

b.Subsistem Usahatani atau proses produksi

Sub sistem ini mencakup kegiatan pembinaan dan pengembangan usahatani dalam rangka meningkatkan produksi .Termasuk kedalam kegiatan ini adalah perencanaan pemilihan lokasi, komoditas, teknologi, dan pola usahatani dalam rangka meningkatkan produksi. Biaya produksi adalah keseluruhan biaya yang dikeluarkan produsen untuk menghasilkan suatu barang.Untuk mencapai profit 
maksimum, produsen harus memproduksi barang sampai pada tingkat dimana biaya marginal sama dengan penerimaan marginal.Menurut Ida Nuraini ( 2013), dalam teori produksi dikenal adanya biaya produksi jangka pendek dan biaya produksi jangka panjang.Biaya produksi jangka pendek meliputi biaya tetap ( fixed Cost) dan biaya berubah (Variable Cost). Biaya tetap adalah biaya yang dikeluarkan oleh perusahaan untuk menghasilkan output tertentu,yang manabiaya tersebut besarnya tetap tidak tergantung dari output yang dihasilkan.Biaya seperti ini biasa di sebut dengan biaya overhead atau biaya yang tidak dapat dihindari (unavoidable). Sedangkan dalamm produksi jangka pendek semua biaya dalah biayaa berubah.Biaya berubah adalah biaya yang besarnya berubah-ubah tergantung dari sedikit banyaknya jumlah output yang dihasilkan. Biaya ini sering disebut dengaan biaya langsung atau biaya yang dapat dihindari (avoidable cost).

c.Subsistem Agroindustri/pengolahan hasil pertania

Pengolahan hasil pertanian antara lain :

- Pembersihan, Pembersihan dimaksudkan untuk menghindari kerusakan yang tinggi pada hasil pertanian, sebaiknya segera dilakukan pembersihan agar hasil pertanian terbebas dari kotoran, hama dan penyakit. Pembersihan dapat menggunakan air bersih.Hasil pertanian yang telah dicuci selanjutnya ditiriskan agar terbebas dari sisa air yang mungkin masih melekat dan ditempatkan pada tempat tertentu.

- Standarnisasi dan Grading, standarnisasi di maksudkan untuk menetukakan standar terlebih dahulu terhadap produk . Grading di maksudkan untuk memilah barang sesuai dengan standar yang telah di tentukan. Penggolongan dilakukan berdasarkan berat, besar, bentuk / rupa, warna dan bebas dari penyakit dan cacat lainnya.

d.Pengemasan,Pengemasan berfungsi untuk melindungi dari kerusakan, menciptakan daya tarik bagi konsumen dan memberikan nilai tambah produk e.Subsistem Pemasaran

Pemasaran adalah aktivitas lebih lanjut setelah barang dan jasa di produksi. 
Menurut Philip Kotler ( 1997 ) Pemasaran adalah sejumlah kegiatan bisnis yang ditujukan untuk member kupuasan dari barang atau jasa yang dipertukarkan kepada konsumen atau pemakai.

William J.Stanton Basu Swasta, (1992). , medifinisikan Pemasaran adalah ssuatu system keseluruhan dari kegiatan-kegiatan bisnis yang di tujukan untuk merencanakan,menentukan harga,mempromosikan dan mendistribusikan barang dan jasa yang memuskan kebutuhan baik kepada pembeli yang ada maupun pembeli potensial.

Gumbira-Sa'id,E.(2001) menjelaskan Pemasaran adalah sejumlah kegiatan bisnis yang ditujukan untuk member kepuasan dari barang atau jasa yang dipertukarkan kepada konsumen atau pemakai dalam bidang pertanian,baik input maupun produk pertanian. Dari pengertian tersebut pengertian pemasaran tidak hanya terbatas kepada aktivitas jual-beli barang, tapi menyangkut bagaimana barang yang di produksi bisa di distribusikan kepada konsumen.

Fungsi pemasaaran memiliki peraanan yang sangat penting dalam mendistribusikan barang dari produsen ke konsumen dan memberikan nilai tambah yang besar dalam perekonomian. Klasifikasi fungsi-fungsi pemasaran menurut Gumbira Sa'id,E (2001) adalah sebagai berikut:

Fungsi pertukaran, fungsi usaha untuk melakukan pembelian dan penjualan

1) Fungsi pisik pemasaran meliputi : fungsi untuk penyimpanan, fungsi untuk pengangkutan, fungsi pengolahan ).

2) Fungsi fasilitas pemasaran ,meliputi: fungsi standarnisasi dan penggolongan produk, fungsi usaha pembiayaan, f ungsi penanggungan resiko,dan fungsi penyediaan informasi pasar.

Sub sistem pemasaran mencakup pemasaran hasil-hasil usahatani baik untuk dalam negeri maupun luar negeri. Kegiatan pemasaran memegang peranan penting agar dapat memberikan keuntungan yang maksimal.Kegiatan pemasaran erat kaitannnya dengan aktivitas usaha tani dan pengolahan hasil pertanian.Usaha tani dan pengolahan hasil pertanian yang sukses tidak ada artinya kalau tidak di tunjang dengan kesuksesan di bidang pemasaran.

Sub sistem pendukung adalah semua jenis kegiatan yang menggunakan 
output pertanian menjadi input untuk menjalankan usahanya lebih lanjut.Atau dengan kata lain adalah semua jenis usaha yang berbasis pada uotput pertanian.

\section{Metode Penelitian}

\section{Lokasi Penelitian}

Lokasi penelitian dilakukan di Kecamatan Sukorambi Kabupaten Jember.Penentuan lokasi penelitian ditetapkan secara sengaja karena didaerah Sukorambi banyak yang melakukan budidaya sayur-sayuran seperti Sawi dan padi. Populasi dan Sampel

Populasi dalam penelitian ini adalah petani sayuran Sawi dan padi yang ada di Kecamatan Sukorambi Jember, pengambilan sampel di lakukan dengan sistim Bola Salju ( Snowball Sampling ) khusus untuk petani yang menanam sayuran sawi dan padi dengan jumlah smpel secara keseluruhan 20 petani sayuran sawi dan padi. Petani dalam melakuknan usaha tani sayuran sangat bervariasi, ada yang khusus menanam sayuran sawi ada yang menanam berbagai jenis sayuran seperti sawi, kangkung ,bayam,kenikir dsb dalam satu areal.sampel yang di ambil dalam penelitian ini khusus yang menanam sayuran Sawi dalam satu areal.

\section{Pengumpulan Data}

Data di kumpulkan secara langsung kepada petani sayur yang ada di Kecamatan Sukorambi Jember yang di pandu dengan kuisioner.Data sekunder tentang tanaman sayuran sawi dan padi di Kecamatan Sukorambi Jember di peroleh dari BPS Jember

\section{Model analisis}

Model analisis yang di gunakan untuk mengetahui rasio pendapatan antara sayuran sawi dan padi, digunakan formula sebagai berikut :

1. Analisa pendapatan di gunakan formulasi yang di gunakan oleh

Soekartawi, (1996)

$$
\begin{aligned}
& \Pi=\mathrm{TR}-\mathrm{TC} \\
& \mathrm{TR}=\mathrm{P}_{\mathrm{y}} \cdot \mathrm{Y} \\
& \mathrm{TC}=\sum_{i=1}^{n} P i \cdot X i-\mathrm{k} \\
& \mathrm{FC}=\mathrm{k}
\end{aligned}
$$




$$
\begin{aligned}
& \mathrm{VC}=\sum_{i=1}^{n} P i . X i \\
& \Pi=\left[(\boldsymbol{P} i . Y)-\left(\sum_{i=1}^{n} \boldsymbol{P} i . X i-k\right)\right]
\end{aligned}
$$

Keterangan:

a. $\Pi=$ Profit / keuntungan $(\mathrm{Rp})$

b. TR=Total Revenue/ Total penerimaan usaha tani (Rp)

c. $\mathrm{TC}=$ Total Cost/Biaya total usaha tani $(\mathrm{Rp})$

d. $\mathrm{FC}=$ Fixed Coast/ Biaya tetap $(\mathrm{Rp})$

e. $\mathrm{VC}=$ Variable cost/ Biaya variabel $(\mathrm{Rp})$

f. $\mathrm{Py}=$ Price/harga output $(\mathrm{Rp} / \mathrm{Kg})$

g. Y=Produksi yang diperoleh dalam usaha tani $(\mathrm{kg})$

h. $\mathrm{Pi}=$ Harga input variabel (Rp/satuan)

i. $\mathrm{Xi}=\mathrm{Jumlah}$ input yang membentuk biaya variabel

2.Analisa efisiensi usahatani digunakan pendekatan R/C Ratio yang rumusnya sebagai berikut ( Hermanto,1991).

$$
\text { R/C = } \frac{\text { Total Penerimaan }}{\text { Total Biaya }}
$$

Kreteria pengambilan keputusan :

1. $\mathrm{R} / \mathrm{C} \geq 1$ maka usahatani efisien

2. $\mathrm{R} / \mathrm{C} \leq 1$ maka usahatani tidak efisien

3. Semakin tinggi nilai $\mathrm{R} / \mathrm{C}$ Ratio ,maka semakin tinggi daya saing komuditas.

3. Model analisis yang di gunakan untuk menganalis perbandingan pendapatan petani sayuran Sawi dengan petani padi adalah uji Mann-Whitney, ( Singgih Santoso ,2000). rumus yang digunakan adalah sebagai berikut:

$$
U=n_{1} n_{2}+\frac{n_{2}\left(n_{2}+1\right)}{2}-\sum_{i=n_{1}+1}^{n_{2}} R
$$

Dimana:

$\mathrm{U}=$ Nilai uji Mann-Whitney

$\mathrm{N}_{1}=$ sampel 1

$\mathrm{N}_{2}=$ sampel 2

$\mathrm{R}_{\mathrm{i}}=$ Ranking ukuran sampel 
Dasar pengambilan Keputusan :

1.Jika nilai signifikasi atau Asymp.sig ( 2-tailed) lebih kecil dari probabiltas 0,05,maka hipotesis atau Ha di terima.

2.Jika nilai signifikasi atau Asymp.sig ( 2-tailed) lebih besar dari probabilitas 0,05, maka hipotesis atau Ha di tolak

\section{Hasil Dan Pembahasan}

\section{Keuntungan Usaha Tani}

Dalam dunia bisnis, memperoleh keuntungan adalah target akhir dari setiap usaha. Dalam budidaya tanaman khususnya tanaman sayuran sawi dan padi tidak terlepas dari upaya untuk memperoleh keuntungan. Segala upaya ditempuh oleh petani untuk bagaimana mengeluarkan biaya yang tertentu untuk memperoleh keuntungan yang maksimum. Efisiensi biaya di usahakan sedemikian rupa untuk memperoleh produksi optimal.

Keuntungan usaha tani adalah formula dari total penerimaan dikurangi dengan biaya-biaya yang harus dikeluarkan oleh petani dalam memproduksi sayuran tertentu yang dalam hal ini adalah sayuran sawi dan padi .Pemikiran petani sayuran sawi dan padi adalah bagaimana dari sisi produksi bisa optimal dengan biaya yang sedemikian rupa (efisien ). Bagaiman kuantitas dan kualitas produksi bisa maksimal dengan biaya tertentu.

Masalah harga produksi sayuranSawi bersifat kondisional, dalam arti kalau penawaran satur-sayuran melimpah karena banyak petani yang berlomba-lomba membudidayakan sayuran sawi tersebut dan di dukung oleh cuaca yang memungkinkan seperti pada saat musim kemarau; maka posisi petani dalam hal harga sayuran sawi tersebut adalah penerima harga.artinya harga ditentukan oleh tengkulak tingkat desa, petani tidak dapat menetukan harga jual. Sebaliknya pada saat musim hujan budidaya tanaman sayur sayuran seperti sawi, supplainya terbatas,banyak petani yang gagal dalam usaha taninya karena faktor cuaca. Ratarata petani bayak gagal didalam proses produsinya,sehingga suplainya terbatas. Dalam kondisi yang demikian penentu harga dalam tanda petik ditentukan oleh petani ,sehaingga terjadi kenaikan harga yang nyata bila dibanding pada saat musim hujan. Jadi dari sisi usaha tani ,produksi bagus kalau tidak diikuti oleh harga jaul 
yang bagus, keuntungan petani bisa rendah bahkan bisa merugi.Sebaliknya pada saat musim kemarau cuaca sangat mendukung, sehingga banyak petani yang mengusahakan sayuran sawi,yang berdampak pada over produksi, sehingga harganya sangat murah.Untuk tanaman padi pada saat musim kemarau dari sisi produksi jumlahnya relatif berkurang di banding musum hujan, hanya saja harganya lebih tinggi bila dibanding musim hujan.

Persoalan tehnis budidaya sayuran sawi dan padi telah dikuasai oleh petani di Sukorambi, karena budidaya sayuran sawi dan padi telah bersfat turun temurun. Jadi kalau soal budidaya merupakan urusan internal yang telah betul-betul dikuasai oleh petani,dalam arti bagaimana membuat sayuran sawi dan padi tersebut produksinya tinggi ..

Ada tiga komponen yang harus menjadi fokus pemikiran dari petani sayuran sawi dan padi adalah menyangkut bagaimana menggunakan input sedemikian rupa yang bisa mengoptimalkan hasil produksinya, efisiensi biaya dan harga jual, atau dengan kata lain bagaimana mencapai efisiensi teknis, harga dan ekonomis.

Tabel 1.Rata-Rata Pendapatan Usaha Tani Sayuran Sawi Per $1750 \mathrm{~m}^{2 /} \mathrm{Rp}$

\begin{tabular}{|l|l|l|}
\hline NO & Uraian & Total \\
\hline 1 & $24 \times 250$ ikat $\times 700$ & 4.200 .000 \\
\hline
\end{tabular}

Luas lahan $1750 \mathrm{~m}^{2}$, berisi 24 gulud, tiap gulud berisi 750 tanaman dengan jarak tanam $10 \times 20 \mathrm{~cm}$. Tiap gulud rata dapat 250 ikat, per ikat di jual pada pedagang desa Rp.700. Petani sayuran sawi dapat pula menjual hasil produksinya dengan cara di tebaskan.Pedagang tingkat desa rata-rata membeli dengan harga Rp.80.000 s/d Rp 90.000.Jika petani menjual dengan cara di tebaskan ,maka pendapatan petani hanya berkisar Rp. $1.920 .000 \mathrm{~s} / \mathrm{d}$ Rp.2.160.000.

Tabel 2.Rata-Rata Biaya Usaha Tani Sayuran Sawi Per $1750 \mathrm{~m}^{2 /} \mathrm{Rp}$

\begin{tabular}{|l|l|r|}
\hline NO & Uraian & Total \\
\hline 1 & Bibit 24 x 15.000/ 0,5 cangkir & 360.000 \\
\hline 2 & $\begin{array}{l}\text { Pengolahan lahan (membuat Guludan).24 } \\
\text { gulud a.7000 }\end{array}$ & 168.000 \\
\hline 3 & Ongkos tanam 24 x 15000 & 360.000 \\
\hline 4 & Pupuk urea 1 sak & 90.000 \\
\hline 5 & Pupuk kandang 24 x 5000 & 120.000 \\
\hline
\end{tabular}




\begin{tabular}{|r|l|r|}
\hline 6 & Obat- obatan & 120.000 \\
\hline 7 & Penyiraman & 1.068 .000 \\
\hline 8 & Ongkos panen sampai mengikat 24x 10.000 & 240.000 \\
\hline & Total biaya & 2.526 .000 \\
\hline
\end{tabular}

Luas lahan $1750 \mathrm{~m}^{2}$ berisi sayuran sawi lebih kurang 18.000 batang.Total biaya rata-rata yang di perlukan untuk usaha tani tersebut untuk sekali tanam Rp.2.526.000.Untuk biaya tetap rata-rata petani mengabaikan penyusutan. Sehingga dalam kalkulasi biaya, hal tersebut tidak nampak.hal ini bisa terjadi karena pembuatan guludan pada umumnya di tebaskan.

Total keuntungan untuk sekali panen untuk sayuran sawi adalah Rp.4.200.000- Rp.2.526.000 = 1.674.000. Sehingga untuk 3 kali panen yang setara dengan 1 kali musim padi adalah Rp.5.022.000

Tabel 3.Rata-Rata Pendapatan Usaha Tani padi

\begin{tabular}{|l|l|l|}
\multicolumn{3}{|c|}{ Per $1750 \mathrm{~m}^{2 /} \mathrm{Rp}$} \\
\hline 1 & Uraian & Total \\
\hline
\end{tabular}

Produksi rata-rata untuk luas lahan $1750 \mathrm{~m}^{2}$ yang memerlukan bibit padi sebanyak $10 \mathrm{~kg}$ adalah $10 \mathrm{kwt}$. Harga yang berlaku saat panen rata-rata Rp 4200/kg.Petani padi sebenarnya mempunyai alternatif lain dalam menjual hasil produksinya,misalnya dengan sistem tebasan. Banyak pedagang dari lokal maupun luar daerah yang berminat bermain dengan pembelian sistem tebasan.Sistem tebasan sebenarnya sangat menguntungkan petani padi karena tidak mengeluarkan biaya panen.Tetapi petani sering mengalami masaalah dengan sistem tebasan yaitu soal pembayaran.dimana pada umumnya pedagang hanya membayar uang muka sedang sisanya di bayar setelah panen.pedagang jika mengalami kerugian dari sistem tebasan tersebut minta potongan pada petani bahkan petani tidak di bayar, yang dalam hal ini masuk kalkulasi hutang. Hal resiko yang paling parah dengan sistim tebasan adalah keterlambatan penebas dalam memanen padi.Keterlambatan ini mengakibatkan banyak padi yang rontok karena padi sudah terlalu tua.Jika dari sudut pandang penebas jumlah padi yang rontok banyak dan diperkirakan rugi,maka penebas tidak segan-segan untuk merelakan uang muka tebasan. Hal ini sangat merugikan petani padi. 
Tabel 4 Rata-Rata Biaya Usaha Tani padi

Per $1750 \mathrm{~m}^{2 /} \mathrm{Rp}$

\begin{tabular}{|l|l|r|}
\hline NO & Uraian & Total \\
\hline 1 & Bibit 10 kg & 90.000 \\
\hline 2 & $\begin{array}{l}\text { 1 Rol Palsik untuk melindungi serangan } \\
\text { hama di lahan persemaian }\end{array}$ & 40.000 \\
\hline 3 & Pengolahan lahan (ongkos Traktor) & 250.000 \\
\hline 4 & $\begin{array}{l}\text { Buat tempat uritan s/d sebar uritan ke lahan } \\
\text { ( 10 orang) }\end{array}$ & 500.000 \\
\hline 5 & Biaya tanam (borongan ) & 100.000 \\
\hline 6 & Pupuk urea Phonska,organik & 225.000 \\
\hline 7 & Pupuk kandang 24 x 5000 & 120.000 \\
\hline 8 & Obat- obatan & 25.000 \\
\hline 9 & Air & 300.000 \\
\hline 10 & Penyiangan 10 0rang & 400.000 \\
\hline 11 & Biaya panen & 150.000 \\
\hline 12 & Ongkos Dores & 150.000 \\
\hline 13 & Ongkos angkut & 245.000 \\
\hline 13 & $\begin{array}{l}\text { Konsumsi mulai awal pengerjaan sampai } \\
\text { dengan panen }\end{array}$ & 2.745 .000 \\
\hline & Total biaya & \\
\hline & $\quad$ & \\
\hline
\end{tabular}

Luas lahan $1750 \mathrm{~m}^{2}$ untuk budidaya tanaman padi biaya yang di perlukan untuk sekali tanam rata-rata Rp.2.745.000.Untuk biaya tetap rata-rata petani mengabaikan penyusutan. Sehingga dalam kalkulasi biaya, hal tersebut tidak nampak,.hal ini bisa terjadi karena pengolahan lahn umumnya di tebaskan.Begitu pula untuk tangki obat-obatan rata-rata petani sewa..

Total keuntungan untuk sekali panen untuk tanaman padi sebesar Rp. 4.400.000- Rp. $2.745 .000=$ Rp.1.655.000

Petani padi juga bisa menempuh alternatif lain dalam menjual hasil produksi padinya.Ada yang model di tebaskan, namun harganya bervariasi sekalai.harga tebasan bisa diatas atau di bawah harga bila petani menjual produksi padinya langsung ke tengkulak yang ada di tinkat desa.Hal ini juga dilakukan oleh petani karena dari sisi pembayaran kurang aman.

Tabel 5 Rata-Rata Keuntungan sayuran sawi dan padi

Per $1750 \mathrm{~m}^{2 /} \mathrm{Rp}$

\begin{tabular}{|l|l|l|l|l|}
\hline No & Komoditas & Total Penerimaan & Total Biaya & Keuntungan \\
\hline 1 & Sayuran Sawi & 12.600 .000 & 8.235 .000 & 4.365 .000 \\
\hline 2 & Padi & 4.400 .000 & 2.745 .000 & 1.655 .000 \\
\hline
\end{tabular}


Dari tabel 5 nampak bahwa keuntungan menanam sayuran sawi 2,6 kali lipat bila di banding dengan menanam padi.Disamping itu menanam sayuran sawi memiliki kelebihan bahwa petani dapat memperoleh keuntungan secara bertahahap , yaitu tiap bulan bila di banding dengan tanaman padi yang baru memperoleh penghasilan sekitar 4 bulan.

\section{Analisis R/C Rasio usaha Tani}

Salah satu tolak ukur apakah suatu usaha layak di jalankan atau tidak ,digunakan $\mathrm{R} / \mathrm{C}$ rasio. $\mathrm{R} / \mathrm{C}$ rasio adalah perbandingan antara total penerinaan dengan biaya-biaya produksi. Kreteria pangmbilan keputusan :

a. $\mathrm{R} / \mathrm{C}>1$, maka usaha tani layak

b. R/C $<1$, Maka usaha tani tidak layak

Berikut di sajikan tabel Nilai R/C Rasio Usaha Tani sayuran sawi dan padi

Tabel 6. Nilai R/C Rasio Usaha Tani Sayuran Sawi dan padi

\begin{tabular}{|l|l|l|l|}
\hline Luas lahan & $\begin{array}{l}\text { Biaya Produksi } \\
(\mathrm{Rp})\end{array}$ & $\begin{array}{l}\text { Penerimaan } \\
(\mathrm{Rp})\end{array}$ & $\begin{array}{l}\text { Nilai } \\
\text { R/C }\end{array}$ \\
\hline \multicolumn{4}{|c|}{ R/C Ratio Usaha Tani Sayuran Sawi } \\
\hline $1750 \mathrm{~m}^{2}$ & 7.578 .000 & 12.600 .000 & 1,66 \\
\hline \multicolumn{4}{|l|}{ R/C Ratio Usaha Tani Padi } \\
\hline $1750 \mathrm{~m}^{2}$ & 2.745 .000 & 4.400 .000 & 1.60 \\
\hline
\end{tabular}

Pada tabel 5.diatas nampak bahwa sayuran sawi dan padi tersebut memiliki $\mathrm{R} / \mathrm{C}$ rasio $>1$.Hal berarti sayuran sawi dan padi tersebut layak untuk diusahakan. Walaupun layak di usahakan tapi harus dikaitkan dengan skala usaha. Jika diperhatikan dari sisi $\mathrm{R} / \mathrm{C}$ ratio,sayuran sawi dan padi memiliki daya saing yang lebih tinggi bila dibanding dengan padi.

\section{Analisis Perbandingan Pendapatan usaha tani sayuran sawi dan padi.}

Model analisis yang di gunakan untuk menganalis perbandingan pendapatan petani sayuran sawi dengan petani padi adalah uji Mann-Whitney,

Dari hasil perhitungan pada lampiran ,Nilai signifikasi atau Asymp.sig . dalam uji Mann Whitney $=0,000$, hal ini lebih kecil dari nilai probabilitas 0,05.Artinya Ha.di terima atau dengan kata lain ada perbedaan yang nyata pendapatan atau keuntungan yang di terima petani sawi dengan petani padi 


\section{Kesimpulan}

Usaha tani Sayuran Sawi di Daerah Sukorambi tergolong Usaha mikro dan masih bersifat tradisional. Dilihat dari keuntungan aktual/nominal, Sayuran Sawi memiliki keuntungan 2,6 kali bila dibanding dengan tanaman padi. Dilihat dari analisis R/C rasio, tanaman sayuran sawi dan padi sama-sama layak untuk di usahakan.Hanya saja tergantung pada skala usaha masing-masing tanaman.Sayuran Sawi memiliki daya saing yang lebih tinggi dibanding dengan padi. Analisis perbandingan pendapatan ( keuntungan) menunjukkan bahwa keuntungan menanam sayuran sawi berbeda nyata bila di bandingkan dengan keuntungan mananam padi. Petani dari sisi kalitatif merasa lebih di untungkan menanam sayuran sawi bila di banding dengan menanam padi ,karena tiap bulan bisa menerima keuntungan atau pendapatan bila di banding menenm padi yang memakan waktu 4 bulan sekali. Proses usaha tani sayuran sawi lebih berat di banding dengan menanam padi.

Saran untuk penelitian selanjutnya diantaranya Budidaya sayuran sawi masih dilaksanakan secara tradisional, sehingga perlu adanya sentuhan tehnologi agar keuntungan bisa lebih ditngkatkan; Hendaknya petani padi tidak monoton dalam melakukan usaha tani. Dalam melakukan usaha tani,petani padi hendaknya berorientasi pada keuntungan. Jika menanam sayuran sawi lebih menguntungkan di banding menanam padi,maka ada baiknya tidak menanam padi secara terus menerus.

\section{Daftar Pustaka}

Ida Nuraeni,2013. Pengantar Ekonomi Mikro,Universitias Muhammadiyah Malang.

Gumbira-Sa'id,E,2001.Manajemen Agribisnis, Ghalia Indonesia

Jay Heizer ,Barry Render,2011.Manajemen Operasi.Buku 1 Edisi 9,Salemba Empat Jakarta

J.Stanton ( Basu Swasta, 1977).Azaz-Azas Marketing. Libeety Yogyakarta Maspur dan Shophal Jamil 2007.Analisis Daya Saing Beberapa Jenis Sayuran Di Lahan Sawah Muhammad Firdaus,2012. Manaajemen Agribisnis,Bumi Aksara 
Muhammad Firdaus,2016. Skala Prioritas Dan Strategi Pengembangan Usahatani Hortikultura Di Kabupaten Jember.

Philip Kotler ( 1997 ) Marketing Management:

Analysis,Planning,Implementation, and Control,

Ramli,R dan Dewa KS.Swastika,2005 Analisis keunggulan kompetitif Beberapa Tanaman Palawija di Lahan Pasang Surut Kalimantan Tengah.Jurnal Pengkajian dan Pengembangan Teknologi Pertanian Vol 8,No.1 Maret 2005 : 67-77

Soekartawi (1988).Manajemen Pemasaran hasi-hasil Pertanian, Rajawali Pers.Jakarta

https://www.academia.edu/22690610/Makalah_agribisnis

Saragih, bungaran. Refleksi Agribisnis. Bogor: IPB

Press.http://www.mb.ipb.ac.id/artikel/view/id/fdabc8a88141a4c1c81d24bbf 7927db0.html

http://agribisnis.umm.ac.id/id/umm-news-2489-bidang-ilmu-agribisnis-apa-ituagribisnis-.html 